\title{
Synthetic biology ethically evaluated: The creating God and co-creating human
}

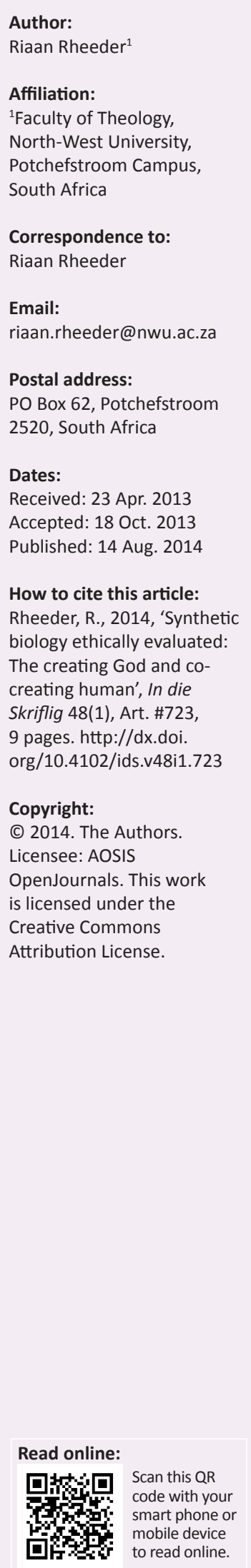

God did not create once and then put an end to it. Testimony from Scripture shows that God continuously establishes or creates new things. Humans can therefore expect to always see and experience new things in creation. With this pattern of reasoning, one can anticipate that the human being as image of God will continuously establish new things in history. Although nature has value, it does not have absolute value and therefore it can be synthesised responsibly. The thought that humans are stewards of God is no longer adequate to, theologically put into words, the relationship human beings have with nature. New biotechnological developments ask for different answers from Scripture. Several ethicists are of the opinion that the theological construction of humans and created co-creators can help found the relationship of the human being to nature. Humans developed as God's image evolutionary. On the one hand, this means humans themselves are a product of nature. On the other hand, the fact that humans are the image of God is also an ethical call that humans, like God, have to develop and create new things throughout history. Synthetic biology can be evaluated as technology that is possible, because humans are the image of God. However, it should, without a doubt, be executed responsibly.

Sintetiese biologie eties geëvalueer: Die skeppende God en medeskeppende mens. God het nie net eenmaal geskep en daar gestop nie. Uit Skrifgetuienisse kan afgelei word dat God voortdurend nuwe dinge tot stand bring of skep. Daarom kan die mens verwag om gedurig nuwe dinge in die skepping te sien en te beleef. Hiermee saam kan verwag word dat die mens as beeld van God voortdurend nuwe dinge in die geskiedenis tot stand sal bring. Alhoewel die natuur waarde het, het dit nie absolute waarde nie en kan dus verantwoordelik gesintetiseer word. Die gedagte dat die mens rentmeester van God is, is nie meer voldoende om die mens se verhouding tot die natuur teologies te verwoord nie. Nuwe biotegnologiese ontwikkelinge vra na ander antwoorde vanuit die Skrif. Verskeie etici is van mening dat die teologiese konstruksie van die mens as geskepte medeskepper kan help om die mens se verhouding tot die natuur te begrond. Die mens het deur 'n evolusionêre proses tot God se beeld ontwikkel. Aan die een kant beteken dit dat die mens self 'n produk van die natuur is. Aan die ander kant is beeldskap ook 'n etiese oproep dat die mens, soos God, nuwe dinge in die geskiedenis moet ontwikkel en skep. Sintetiese biologie kan gesien word as tegnologie wat moontlik is omdat die mens na die beeld van God geskape is. Sonder twyfel moet sintetiese biologie egter verantwoordelik beoefen word.

\section{Introduction}

This article should be read in conjunction with the preceding article titled 'An exploration of synthetic biology: A preliminary Christian-ethical assessment of the advantages and disadvantages of synthetic biology'. On 20 May 2010, the Venter Institute in America announced that they have synthesised the entire genome of the organism Mycoplasma mycoides whilst in vitro by means of a computer connected to a machine that synthesises genes. Thereafter, the genome was placed into the casing of another organism (Mycoplasma capricolum) and it was reported that the synthesised genome and organism, as a whole, was functioning normally. This synthesised organism was constructed to function as a little factory with the aim of producing and secreting fuel and medication - something that is not the natural function of either of the organisms that were used.

\section{Hefner (2007) makes the following remark:}

The issues of genetics are among the most challenging that have ever faced the human community. Few issues impinge on our common experience as vividly and urgently as those on the genetic frontier. (p. 183)

This article will pay attention to the intrinsic evaluation of synthetic biology. The Bioethical Commission, which advises the American president regarding bioethical matters, distinguishes 
between a discussion of the advantages and disadvantages of the technology on the one hand, and an intrinsic evaluation of this technology on the other hand, when they address the evaluation of synthetic biology. Intrinsic evaluation refers to the discussion of the question whether this technology is inherently ethical or unethical. In the ethical evaluation of synthetic biology, the Commission makes cursory use of theological arguments (Presidential Commission for the Study of Bioethical Issues [Bioethics Commission] 2010):

The necessity of such a study is well-formulated by Garfinkel et al. (2008) when they note:

In 1971, in describing the content of a talk in a conference he was organizing, Sidney Fox wrote, 'As such processes [of synthetic biology] are brought under control in the laboratory; they have increasing implications for society and its philosophy.' This is perhaps even truer today, as the full implications of the science and engineering are only now being appreciated. (p. 167)

Parens, Johnston and Moses (2009) are correct when they claim that all scientists have their own definite presuppositions in the evaluation of ethical problems and that each person's point of departure is only one of several possibilities. The point of departure for this article is the reformed theological tradition. In light of the lastmentioned remark, this theological-ethical evaluation should not be seen as an adjudication from a stance of moral superiority. It is rather an attempt to share certain views with the scientific community to understand the points of departure of others and to come to a joint conclusion as to what will be to the glory of God and the advantage of man. Garfinkel et al. (2008) is consequently quite relevant with the following remark:

However, there is a clear need for ethicists, theologians, scientists, engineers, policymakers, and the public to understand each others' views on these issues, and such examinations are ongoing. (p. 166)

The central issues this article aims to answer are accurately formulated by Parens et al. (2009) when they write the following in their discussion of synthetic biology:

The appropriate attitude that humans ought to hold toward the natural world, including the extent to which we want to remake ourselves and the world around us, is a familiar concern, but we have not made much progress in exploring it. (p. 25)

What is the believer's legitimate role in creation? Or stated differently, what is the correct relationship of man to creation? From this follows the question: May humans create new (that has never existed, evolutionary) biological living organisms? In answering this question and giving a biblical evaluation of synthetic biology, we will firstly look at God as Creator and the meaning thereof. In this regard, two matters will receive special attention, namely creatio ex nihilio [creation from nothing] and creatio continua [continuous creation]. Consequently, attention will be paid to the human being as the image bearer of God (imago Dei), from which man's relationship to creation can be deducted.

\section{God as Creator God creates new (creatio ex nihilio)}

In reformed theology it is generally confessed that God creates 'from nothing'. This means that God created everything with no substance in his hands (Gn 1, 2; Job 38; Ps 104, NIV). Yet, there are theologians who are of the opinion that the idea of creation from nothing does not come from the Bible. Nonetheless, the confession of 'creation from nothing' presents God in an important manner, namely as a God of great power. The expression refers to the incredible divine ability to call creation as it currently is into existence and to sustain it (Dabrock 2009). König (2001) refers to two further important meanings of ex nihilio when he argues:

Skepping uit niks beteken ook dat Hy skep presies soos Hy wil, dat die skepping presies sal wees soos Hy dit wil hê. En nog verder beteken dit dat wat Hy skep regtig nuut is. Dit is nie iets wat reeds bestaan het wat net verander of nuut gemaak is nie. [Creation from nothing also means that he creates precisely as he wants to, that creation will be exactly as he wants it. Still further it means that what he creates is really new. It is not something that had already existed and that was only changed or renewed.] (p. 71, [author's own translation], cf. Van Genderen \& Velema 1992; Hefner 1993)

Firstly, one can deduce that God shows at the inception of creation that it is part of his nature to create new things things that have never existed before. God alone is the subject of bâra" [creational act] '... en altijd kom ter door het skeppend werk van God iets nieuws tot stand' ['... and something new always comes into being through the creative work of God'] (Van Genderen \& Velema 1992).

Secondly, why does God create new things in particular? In history the purpose of creation has been defined in terms of the glory of God, the covenant and creation itself. The purpose of nature is to glorify God (Rm 11:36; 1 Cor 8:6, NIV). Whether God is 'enriched' by the glory God receives is an old question. Some people are of the opinion that God already has 'everything' - how can something from outside of him then be added unto him? In this regard König (2001) says that the creation of new situations (ex nihilo, things that have never existed before) means that God is enriched (glorified):

Dink 'n oomblik aan nuwe verhoudings waarin Hy staan: Hy was nog nooit tevore Skepper nie, ook nie Onderhouer van die skepping nie. So is dit ook vir Hom nuut om die God van Abraham en Israel te wees, of 'n mens of die Verlosser [...] en so kan 'n mens aangaan. Dit is regtig 'n vreeslike statiese siening oor God dat Hy nooit iets nuuts kan ervaar of verryk kan word nie. [Think for a moment of the new relationships within which he stands: he has never been Creator before, nor has he been the sustainer of creation. It is also new for him to be the God of Abraham and Israel, or a man or the Saviour [...] and so one can go on. It is really a very static view of God that he can never experience something new or be enriched.] (p. 75, [author's own translation])

Thirdly, different theologians agree that the creation ex nihilio also creates the expectation that God will continue to do new things in his further actions. He will not just merely repeat the same old actions. Ex nihilio implies that more things are waiting than what humans think (Hefner 1998; König 2001). 
In light of the above-mentioned, the following can be anticipated of God and man. Firstly, God will continue to create new things with which he will be glorified and with which he will have new experiences. Secondly, God will give humans (as his image bearers) the gift to establish new things with which God may be glorified and with which his existence will be enriched.

\section{God continuously creates a new (creatio continua)}

It is important that a distinction is made between original creation by God (creatio originalis) and God's creative activities throughout history (creatio continua). For ever so long during the theological tradition (and even now), God's creative activity has been limited to the protological creational events during which, according to the first chapters of the Bible, the foundations were laid for natural order and the archetypes of all beings (Pannenberg 2006). In theological discussion, God's involvement after the initial creation is greatly limited to conservation and similar activities. This idea does not leave much room for the emergence of meaningful new things in the later phases of world history.

Moltmann (1985) mentions that the evolution theory ${ }^{1}$ shows that special attention should be paid to the neglected doctrine of continuous creation (creatio continua). Berkhof (1985) is also of the opinion that the rise of evolution theory as manner of creation has stimulated the doctrine of continuous creation. Pannenberg (2006) writes:

It was therefore with good reason that the idea of a 'continuing creation' has been increasingly emphasized by those involved in the dialogue between theology and science, especially after the dispute over Darwinism. (p. 364)

The idea of a statically completed world etched out by an artist, has to make way for a dynamic view of an unfolding creative process (Polkinghorne 2006). Creation has not been completed and remains incomplete (Hansen \& Schotsman 2005). As the world moves on and history develops, new things appear (Peters 2005:857). According to Berkhof (ibid), creation by God should not be viewed as a completed matter (Dabrock 2009), but should be seen as a continuous process and as part of God's providence.

Every new plant, animal or person (through ordinary procreation) means that something new is emerging. Throughout the history of creation, there has been evidence of new plants and animals appearing and disappearing. In light of the above, we cannot say God was the Creator. He is the Creator: the continuous, creative process is orderly, stable and comprehensible and therefore a reflection of God's character (Crook 2007). Polkinghorne (2006) writes:

God is as much the Creator today as God was 13.7 billion years ago, when the universe as we know it emerged from the singular state of the big bang. (p. 60)

The Hebrew word bâra", which refers to God's unique primordial creational acts in the beginning (Gn 1:1, NIV), is

$1.0 n e$ can also add to this the new knowledge of continental shifts and the formation of the ocean floor (see Dawkins 2009). used more frequently in the rest of the Bible to refer to God's creation of redemption and salvation throughout history than to refer to the creation of heaven and earth (Moltmann 1985; Van Genderen \& Velema 1992).

In prophetic theology, God's continuous creational acts of redemption and salvation are seen as unexpected 'new things' (Is 43:18-21, NIV). ${ }^{2}$ Here God's historical activities of the creation of freedom, justice and redemption (and even new roads and rivers) are not described as the mere sustenance of that which was created before, but indeed as the establishment of new things (creatio nova). In Isaiah 48 we see that God uses creational terms and images to describe the return from exile, whilst it is clearly stated in verse 7 that God will create the reality of the return (baira") as something new that has never before existed in history ('âz). Later the Lord says that 'He will make her [Zion] deserts like Eden, her wastelands like the garden of the Lord' (Is 51:3, NIV; see König 2010). Barra” refers to God's creational act in history (Van Genderen \& Velema 1992). Although the above-mentioned creations are mainly manifested in human cultural history, the creation of new things is also seen and experienced in the history of nature like, for instance the creation of new rivers and landscapes. In conjunction with this, according to Pannenberg (2006), Psalm 104:303 indicates that God works creatively in creation all the time (cf. Moltmann 1985). What is more, the New Testament refers to 'a new creation in Christ', 'life-giving Spirit' and the eschatological promise of 'making everything new'. Merely limiting God's creational activities to the creation in the beginning reflects an ancient cosmology rather than reflecting the golden thread that occurs right throughout Scripture.

There is no strain between creatio continua and creatio ex nihilo - it can be used as supplementary concepts. Creatio ex nihilo means that God did indeed start all of creation, but it can be used as synonymous to creatio continua, because the term merely indicates that something that did not exist before, does exist now (Rm 4:17). In this sense, the concept of creation ex nihilo not only refers to the beginning of creation, but can be applied to every entity that comes into being throughout the history of the world (Pannenberg 2006).

The incarnation of Christ forms the culmination of God's continuous creation in history (Col 1:15, NIV; Pannenberg 2006). Moltmann (1985) also supports this idea and sees Christ as the new servant of God. The continuous creation of God is not an easy process and is fulfilled amidst much resistance. In Isaiah 43, which deals with the fact that God will bring forth new things (v. 19), one finds that God has been burdened and put to trouble (v. 24). The establishment of a new situation of redemption and forgiveness took place through the wounds of Christ (Is 53:5, NIV; Moltmann ibid). The formation of new things in human history (like what

2.'Forget the former things; do not dwell on the past. See, I am doing a new thing Now it springs up do you not perceive it? I am making a way in the desert and Now it springs up; do you not perceive it? I am making a way in the desert and streams in the wasteland. The wild animals honor me, the jackals and the owls, because I provide water in the desert and streams in a wasteland, to give drink to my people, my chosen, the people who I formed for myself that they may proclaim my praise.'

3.'When you send your Spirit, they are created, and you renew the face of the earth.' 
happens during synthetic biology) is therefore not always an easy process and will be met with resistance and effort.

The Roman Catholic confession, De Nieuwe Katechismus (1966), summarises the meaning and implication of creatio continua as follows:

Beter dan te zeggen God hééft geschapen, is het te zeggen: God schept [...] Dat God schepper is, betekent dat alles wat bestaat van Hem afhankelijk is, dat alles hangt aan Hem. Om God als schepper te beseffen, moeten wij niet zozeer denken aan het begin, maar aan het nu, en aan de toekomst. Hij is nu aan het voltooien [...] God heeft de wêreld niet geschapen. Hij is de wêreld aan het scheppen, en dat doet Hij ook door ons [...] Wat de mens maakt, is schepping van God. [Rather than saying that God has created, we should say: God creates [...] The fact that God is Creator means that all that exists depend on him, that all rely on him. To realise that God is the Creator, we should not just think of the beginning, but of now, and the future. He is busy completing now [...] God did not create the world. He is creating the world, and this he also does through us [...] What humans do, is creation by God.] (pp. 309, 573-574, 501, [author's own translation])

In light of the above argument, it can be anticipated that God will continuously create new things and that humans can indeed be expected to create new things - and it is correct to claim that all good creations humans create, is also the creation of God. This proposal will later be evaluated when man as image of God is discussed.

\section{God creates value}

The question now arises whether micro-organisms (as part of God's creation) have any (intrinsic) value - a kind of non-human dignity - which would make it unethical from a biblical point of view to synthesise or even wholly create these creatures. Do these organisms have rights (Vorster 2004)? The Swiss government legally compelled its federal bioethical commission to deal with this issue in their study report ${ }^{4}$ (Federal Ethics Committee on Non-Human Biotechnology (ECNH) 2010).

The anthropocentric tradition departs from the point of view that only humans, due to their consciousness, have intrinsic value. The created reality only has instrumental value or value in as far as it is useful to humans (ECNH 2010). Synthetic biology therefore poses no ethical problems. The non-anthropocentric tradition departs from the point of view that the created reality has value, regardless of whether it is useful to humans (ECNH 2010). Vorster (2011) is of the opinion that the remarkable value of nature, including organisms (see ECNH 2010), can be deducted from the creation narrative:

1. The value of nature in relation to God. Creation (including humans) has value, because its origin lies in God. Creation originated from God's breath. Furthermore, nature has value, because God dwells in it through his

4. However, the context of constitutional law within which the present discussion is being conducted calls for examination of the question of inherent value. Under Article 120 of the Swiss Federal Constitution, the 'dignity of living beings' is to be taken into account in the handling of animals, plants and other organisms (ECNH taken intor.
Spirit - he is present everywhere and sustains it. The special dignity of creation is found in the fact that God wills the existence of every living creature, and gives each its immanent characteristics (qualities). These immanent characteristics mean that all living organisms have created functions and purposes. All organisms fulfil a function in this complex habitat. The priestly narrative mentions that God created animals, plants and also organisms according to their own kind. God is the Creator and therefore the structure of creation reveals something about God's greatness (Gn 1, 2). Nature has inherent value, because it makes humanity aware of God. In Genesis 9 one also finds that God has a covenant with nature, which indicates its intrinsic value.

2. The dignity of nature in relation to humanity. Humans and animals were created on the same day, both come forth from the earth, and they are in their essences closely linked to the earth (and therefore to each other). ${ }^{5}$ One also finds that both humans and animals are referred to as living beings. Human beings are created in God's image, which means that they have value. Because one can deduce from the above that humans and nature are closely linked, one can conclude that nature indeed has value. Nature, without a doubt, does not have the same value as humans, because only humans are created in God's image. The fact that Christ became human gives more value to nature.

Does this dignity (as worth or quality) that is assigned to nature mean those organisms may not be synthesised (utilised)? In my view, humans may harness nature in a responsible manner, and then specifically for the following reasons (see Vorster 2011):

1. God transfers his deliberative characteristic to man, which means that humans (scientists) have the right to deliberate regarding the usefulness of another species for humans. The dignified human as image of God means that the acting person is an ethical being who stands in a relationship with God, other humans and nature.

2. Humans should be holy as God is holy. Therefore this deliberation (and decision) should be done in such a manner that it respects God and promotes the welfare of his creation.

3. Humans, as image of God, have the mandate to rule over nature, which means that humans have a certain power over nature (Gn 1:28, NIV).

4. From the ecological covenant of Genesis 9, one can deduce that humans and animals (nature) does not have the same value (cf. Lk 12:7, NIV), because only humans receive the command not to kill each other and humans receive the right to eat animals (or to destroy them).

The question arises: how much value or interests are to be weighted in the handling of these beings (ECNH 2010)? Man should conserve the interdependent relationship between nature and humans (Gn 2:15, NIV), because both depend on each other for their survival and dignity. The moral weight 5.This is an important testimony to the intimate relation between human and nonhuman creatures (Vorster 2011:91). 
(dignity) of nature is determined by assessing how great the function of that part of nature is within the whole. The greater the role of a part within the whole, the greater the moral weight of that part. Therefore, the manipulation of a mouse will carry less moral weight than for instance the eradication of a large ecosystem such as the Amazon, because this will pose a larger threat to the whole. According to this argument, one can pose that the synthesis of a single cell does not affect the dignity of nature, but if the creation of a synthetic cell ultimately leads to the destruction of other ecosystems of organisms, synthetic biology would be typified as unethical.

In light of the above argumentation that organisms may be utilised, the following two arguments against synthetic biology are not valid:

1. Synthetic biology is accused of a mechanistic view of life that reduces life to the level of a machine (ECNH 2010). Due to the use of synthetic biology, organisms are planned and constructed by a machine in order to function later as machines producing something. Synthetic (live) organisms brought to life are described in physical and construction (production) terms, which objectifies life (for instance biofactories like BioBricks ${ }^{\mathrm{TM}}$ ) and give the impression of a machine. The thought underlying synthetic biology is founded in the engineering sciences. The mechanical organism has an instrumental function within this technology. Such technology fails to do justice to the essence of life (ECNH 2010). In contradiction with this, one can state that the instrumentalisation of organisms cannot be rejected on moral grounds as a matter of course. Even human dignity does not exclude the instrumentalisation of humans. For instance, workers or family members can fulfil instrumental tasks. The dignity of humans is affected when people are improperly (exclusively or excessively) instrumentalised (ECNH 2010).

2. Critics of synthetic biology are of the opinion that this technology will, in the long run, lead to a weakening of society's respect for other and higher forms of life such as animals and humans (Parens et al. 2009). The ethical question asked repeatedly is whether the way in which (primitive) life is thought and talked about (machine, instrument and manipulation), and especially the way it is controlled (designed constructed organismmachines that have to produce), possibly prepare the ground for a serious devaluation of higher and human life in the future. Although these organisms have no inherent value (identical to humans), and even if there is almost no consideration for these living entities, it is still life. Ultimately it can lead to human beings changing their perception of themselves, which could result in the dignity of humanity being threatened (ECNH 2010; Bioethics Commission 2010). In answer to this 'slippery slope' argument, it can also be argued that there should be a clear indication that the manner in which the organisms are treated in synthetic biology, will necessarily lead, now or in future, to an indecent treatment of other living beings, including human beings.
This will have to be argued convincingly: whether and to what degree the idea that underlies synthetic biology changes humanity's perception of it or of other living beings. If changes in human beings' perceptions do occur (in their relationships with and behaviour towards other living beings), one would still have to indicate why these changed perceptions and behaviour are wrong. In addition, one would also have to prove that these changed perceptions not only threaten the perception of humans about themselves, but also the protection of their dignity. The 'slippery slope' argument was especially used during the beginning phases of synthetic biology to point out the dangers of this technology so that the development could be monitored. However, it cannot currently be viewed as powerful enough to justify a veto of synthetic biology (ECNH 2010).

In light of the above argument, one can indeed claim that the utilisation of nature does not harm its dignity. Reconstructing or synthesising nature does not harm the inherent value of nature as God's handiwork.

\section{Human beings as creators Introduction}

The anthropological point of departure of this subsection is the link between the human being and the Christian concept of God. Human beings are the created co-creators, which firstly means that humans were created (evolutionary) by God, and secondly that the essence of the human being is determined by the specific character of God (Hefner 1998).

\section{The stewardship of human beings}

In the discussion of biotechnological developments such as cloning, genetic manipulation and synthetic biology, the discussion regarding the relationship between God and his creation always fell within the theological models of human beings as stewards of God's creation and as created cocreators. A static model of creation underlies the theological confession of human beings as stewards of God's creation (Hansen \& Schotsman 2005). From the point of departure that human beings are stewards of God's creation, God is seen as the Creator of the material cosmos, humanity and the unchanging universal natural laws. The task of human beings is to study the laws of nature. As sovereign ruler of the created order, God determines the future through his providence. God has the sole right regarding certain aspects of creation - a right that humans do not have. When humans enter this terrain, it is seen as 'playing God'.

The moral responsibility of humans as stewards mainly consists of the protection and maintenance of creation. As trustees of both the inner and external (genetic) creation, human beings may not change God's original (i.e. creation) plan. Stewardship departs from a position of a sacred-symbiotic relationship with nature. All nature is therefore static, and internal laws have to be respected. The 'biologically-once-and-for-all-created-to-completion' nature 
teaches humans how to live within the boundaries established by God during the moments of creation. Nature is primordial in the sense that it contains God's original creational will how God wants creation to be and to stay. God made creation as it is and no one may change it. Therefore nature is also complete, stable and optimal. Nature is a demonstration of God's omnipotence. There is no alternative to God's inner and external nature (Hansen \& Schotsman 2005).

According to Hansen and Schotsman (2005), this model is no longer adequate to address the biotechnological developments within a century of biological control. The first problem is that science teaches us that nature is developing. Change and development has become the point of departure of our day. Also, the model of stewardship contains the danger that it can lead to a deterministic view regarding human nature and biotechnology.

\section{Human beings in the image of God (imago Dei) The appearance of human beings}

According to Berkhof (1985) the logical consequence of the dogmatic point of departure of the creatio continua is the fact that human beings do not merely act as God's partners, but in a certain sense create on behalf of (and under the guidance of) God as created co-creators ${ }^{6}$ - and as co-sustainers and corulers. Polkinghorne (2006) agrees, stating that:

This unfolding process of creatio continua is the way in which creatures explore and bring to birth the new possibilities that emerge from the inherent fruitfulness with which the creation has been endowed. (p. 60)

The theological construct of human beings as created cocreators of God was developed by the Lutheran theologian Philip Hefner (1989). Human beings now become God's new tool in the creation of new things on this earth (Cole-Turner 2006). According to Hefner (2005:188; Hansen \& Schotsman 2005), the concept of co-creator is a relevant concept for ethics, and bioethics in particular. For Cole-Turner (ibid) the concept forms the link between God and biotechnology like no other concept within theology. In conjunction with the above-mentioned dogmatic thought (creatio continua), the hypothesis is that human beings are more than only coworkers of God (cooperatores Dei).

Up to now God has created several different organisms through the evolutionary process (Dawkins 2004; Vorster 2011). With the arrival of human beings, God uses evolution and humans to create new things. The evolutionary arrival (creation) of human beings as the crown of God's creation, implies an enormous division in history. From our perspective as human beings, limited by time and space, it seems that God drastically changed his position as Creator and the nature of his relationship with creation. God enters into a completely new relationship to the world. Through a kenotic act, God limited himself in the exercise of his divine power. God gives human beings their own secret essence: the duality of creative freedom and love. In this way, human 6 . Yet the creation that God continues to hold in existence is not a divine puppettheater in which the great Puppet-Master pulls every string' (Polkinghorne 2006:60). beings become the agent (representative) and partner (coworker) of God. This, however, does not mean that God now withdraws from his creation and leaves it completely in the hands of human beings in a Deistic sense (Polkinghorne 2006). According to Hefner (2005) the modern development in biotechnology means that human beings can no longer be viewed as mere co-workers (stewards). God has created, and now God creates through his providential Word (Ps 33:6, as evolutionary natural process according to scientific law). God decides what the object of creation will be like. With synthetic biology God places certain aspects of the (evolutionary) development in the hands of human beings as co-creators, or at least it sets God and human beings, who both create new things continuously, on an analogical footing (Hansen \& Schotsman 2005).?

'We participate with God in the ongoing creative process' writes Hefner (1989:522). Human beings use their cultural freedom and special power to change the historical events, and even evolutionary events. In this way humans are no longer passive subjects of God's creation, but they can indeed create new things to their benefit and for their own health (Hansen \& Schotsman 2005). The Catholic theologian, Karl Rahner, had a similar view of humanity in their relationship to God and the rest of creation early in the seventies of the previous century.

\section{Foundation of human beings as co-creators}

In his discussion of human beings as the image of God, Kuyper (1910:124) says the following: 'Wanneer wij dus zien een al groter wordende macht over de natuur, dan moet ons dit niet verwonderen.' ['When we therefore see ever-increasing dominion over nature, we should not be astonished']. The understanding of human beings as created co-creators takes as point of departure the fact that human beings are created in God's image (Gn 1:26-29; Hefner 2005; Hansen \& Schotsman 2005). The term imago Dei has a long history and there is only moderate consensus about its meaning. With regard to the theological construct of the created co-creator, some theologians (cf. Douma 1997), feel that the concept is not biblical, because he argues that humans are only stewards of creation.

Two things can be deducted from Genesis 1. Firstly, human beings were created by God to his image, are the 'created' cocreators and were 'made' by God, which means that humans are dependent beings. Without God's evolutionary word, human beings would not have existed. Human beings were (and are) dependent on a cosmic and biological prehistory for their current existence and are still dependent on Divine will to continue with this world. The conclusion can be drawn that human beings did not themselves choose to be the co-creators of God. Human beings were either created as co-creators or developed into co-creators (Hefner 1989). Human beings would not have been in the position or have had the ability to be co-creators if it was not for God. According to Hefner (2005), this point constitutes the irony in the expression, because human beings, who can create so powerfully, were created themselves.

7.The prefix co in 'co-creator' suggests that the human stands on an equal footing with God (Hansen \& Schotsman 2005). 
It is of special importance that God created human beings in a very specific manner (Hefner 2005). Human beings were created to the image of God. From this one can deduct how God created humans and, according to Hefner (2007), also with what purpose he created them. Human beings, as the image of God, cannot be understood in any other way than stating that there is a certain similarity between God and human beings. ${ }^{8}$ This does not mean that they are identical, but there is enough similarity to notice the resemblance. If human beings fulfil their purpose, people should be able to see something of God in other human beings. They should also be able to deduct from human behaviour or actions what God is like (Moltmann 2012). We were meant to be the image of God, to show in our comings and goings what God is like and what God does.

The inverse is, without a doubt, also true. God also shows some similarities with human beings, and that is why König (2010) can write:

As ons dus gaan kyk Wie God is, sal ons iets agterkom van hoe ons moet wees. As ons uit die Bybel leer wie en hoe God is, kan ons mos daaruit aflei hoe ons moet wees. [If we then consider who God is, we will know something of how we should be. If we learn from the Bible who and how God is, we can learn how we should be.] (bl. 170, [author's own translation])

Being the image of God means to be analogous to God. It implies a definite task, or stated differently we should act analogous to God. We therefore deduce the anthropology from the theology-narrowed-down. In this regard Hefner (1989:524) states: 'It is the co in co-creator which I wish to emphasize.' The 'co' refers to 'being like God'. In Genesis $1: 26-27$, one finds that humans as image of God is directly linked to quality. God said: 'let us make' ('ašah; v. 26) and God created (baira"; v.27). Human beings as the image of God is not a static concept that shows the conservation of the given - it is definitely a dynamic concept (Hefner 2005). ${ }^{9}$

God created new things in the past (creatio ex nihilo), he presently creates new things (creatio continua), and he promises that he will create new things in the future (Is 65:17, NIV). Since God creates new things, human beings are instructed by God to, similar to him, continuously make or create new things. ${ }^{10}$ Hefner (1989) states it as follows:

God creates and so do we. We are active participants in the ongoing divine work. We make decisions and take actions which determine in part the course of events. Events bring new things. The human race is daily inventing new things which hitherto never existed. It is a dependent co-creation, to be sure; yet there is genuine advance due to the contributions of human ingenuity and energy. (p. 523)

8.König (2010:159) explains it as follows: "In'n beeld van iemand, sê nou maar Nelson Mandela moet hyself herkenbaar wees. Trouens dis selfs ' $n$ vereiste van ' $n$ spotprent: Die persoon wat afgebeeld word, moet herkenbaar wees. Maar in ' $n$ lewensgetroue beeld moet dan baie ooreenkoms wees.' ['In an image of someone, let's say Nelson Mandela, he himself should be recognisable. In fact, it is one of the requirements of political cartoons: The person that is represented should be recognisable. But in an authentic representation there should be even more similarity.']

9.'To consider the imago dei and human dignity, for example, as possessions to be preserved simply does not conform to who we are' (Hefner 2005).

10.According to Peters (2005), the idea of human beings as the created co-creators of God is the most insightful theological interpretation of human beings as image of God in recent theological history.
In light of the above, one can state that being a created cocreator of God is also an ethical concept. To be the image of God is not only a capacity, but also a command to interact with the world creatively, like he does. Furthermore, the concept means that God did not create a passive and receptive human being, but active 'doing' people (Hefner 2005).

The entire concept of human beings as created co-creators is Christologically founded (Hefner 1989:524). Christ is confessed as Creator on the same level as the Father (Jn 1:13, 10; 1 Cor 8:6, NIV; Van Genderen \& Velema 1992; König 2010). Jesus is repeatedly called 'the image of God' in the New Testament (2 Cor 4:4-6; Col 15; Heb 1:3, NIV). According to König (2010), God gives us an example in Christ of his goal with us. We should become and act like Jesus. This would also mean that we have to do the same work (Jn 14:12, NIV). In this sense Jesus, as image of God, is also God's co-creator.

Even nature is created in such a way that it becomes a cocreator of God. Is that not essentially what the process of evolution is? Nature, which also reflects God's nature, continuously creates life. In Genesis 1 we find that God made the plants and that he commanded the earth to bring forth plants, and then the earth brings forth the plants. König (2010) writes:

Hy beveel nie net daar moet plante wees nie en dan is hulle daar nie. En Hy maak ook nie self die plante nie. Die aarde bring hulle voort. [He does not merely command that there should be plants and then they are there. Nor does he make the plants himself. The earth brings them forth.] (bl. 125, [author's own translation])

In addition to this, the value of this concept lies in the fact that the positive relationship between human nature and the technological reason is built into this concept. ${ }^{11}$ This concept explains that God created human beings with the will to create new things and that they can use their rational capacity to do so. The exceptional consequence of this is that rational ability is positively seen. It is part of the mandate and nature of human beings to create technology which enable them bring changes to creation (Peters 2005).

It is clear from the above argumentation that the creative spirit of human beings should be encouraged and promoted. One can also deduce from the concept of human beings as image of God that the intellectual freedom of humans, which makes creativity possible, should be protected (also see Bioethical Commission 2010). Hefner (2007) related the human being as imago Dei to the genetic developments of the 21st century in the following words:

I have said that the issue of genetic engineering is a quintessential human issue; I mean that this is exactly the kind of issue that we should expect to arise, given the basics of human nature and the current state of our science, technology, and cultural predispositions in many societies of the world [...] The challenge

11.In light of the above, Peters (2005:857) says the following: "The science of Athens invites the anthropology of Jerusalem to investigate the present creation, to understand more fully what God has created thus far. What Athens' heir - the technology of modernity - provides for the children of Jerusalem's covenant is the means for pursuing creativity. Technology provides the tools for world betterment even self-improvement. Technology opens the possibilities of guided newness
within the present creation, a newness that anticipates the still future creativity promised by Jerusalem's God.' 
does not arise because we are sinful or perverted in some way; rather, it grows out of the givenness of our human nature and our current situation. It would be very strange if issues such as these did not appear on the scene. (p. 185)

Without a doubt, being the created co-creator of God also implies that human beings are sinful (Gn 3). Being creatures, human beings are subjected to sin, which means that human beings can abuse their creative abilities - a given of which Hefner (2007) is well aware. Cole-Turner (2006) also highlights the danger of only emphasising human beings as co-creators without keeping in mind that the fallen and self-centred co-creator can abuse this technology. However, the possibility of abuse does not negate the fact that human beings are created co-creators.

To summarise, Hansen and Schotsman's (2005) comment on stem cell research is just as applicable to synthetic biology:

In sum, we can say that emphasizing the 'co-creator' pole of humankind as imago Dei implies an invitation to accept the advantages of stem cell research. (p. 44)

\section{Human beings 'playing God'}

Many critics claim that synthetic biology creates 'new living organisms' and in this context 'new life' means, to some, that something was created ex nihilio (in the Christian sense). For this reason it is said that 'human beings play God' (Parens et al. 2009; ECNH 2010). It is interesting that this expression is used more frequently as an accusation by secular critics of this technology than by religious critics (Bioethics Commission 2010). With this expression, critics suggest that human beings are taking over God's creative work, something reserved for God. Human beings are transgressing their boundaries.

In defence it can be said that the creation of these organisms is not ex nihilio, since existing molecules are used. There is a concatenation with existing things (ECNH 2010). Human beings cannot create ex nihilio. König (2010) says the following:

En tog is skepping uit niks 'n belangrike voorstelling. ${ }^{12}$ Dit getuig van die groot mag van God. Ons kan ook iets 'skep', maar het materiaal daarvoor nodig, byvoorbeeld om 'n rok te maak. Maar ons weet ook hierdie materiaal beperk ons. As dit rooi is, kan ons nie ' $n$ wit rok maak nie, as dit sy is, kan ons nie 'n katoenrok maak nie, as dit min is, kan ons nie ' $n$ lang aandrok maak nie. Maar as ons aanvaar dat God uit niks geskep het, beteken dit Hy was nie beperk deur materiaal waaruit Hy geskep het nie. [And yet creation from nothing is an important representation. It testifies to the great power of God. We can also create something, but we need material to do so, for instance to make a dress. We also know that this material limits us. If it is red, we cannot make a white dress, if it is silk, we cannot make a cotton dress, if it is a small piece, we cannot make a long evening dress. But if we accept that God created from nothing, it means that he was not limited by the material from which he created.] (bl. 148, [author's own translation])

12.König (2010) makes a strong case that Scripture does not teach without a doub that God created everything from nothing. Man was created from dust. The expression creatio ex nihilo merely wants to say that God was not limited by his material when he created.
Furthermore, to be created co-creator implies that human beings will never be able to create in the full sense of the word like God (Hansen \& Schotsman 2005) in order to try to 'play God' in this way. Scripture refers to God as the Creator who creates (baira"). This bara" is exclusively linked to God in the Bible. It is something that only he does. The term ex nihilio refers to the incredible divine ability to call creation as it currently is into being and to control it - something that human beings cannot do. In other words, a human being can never be at the same level as God and can therefore not be accused of 'playing God' (Dabrock 2009). This accusation is a false problem statement and a false contradiction.

Other critics of synthetic biology claim that the application of this technology demonstrates that life is nothing more than the 'sum of its parts', and that life can merely be seen as a series of chemical reactions without any mystery and value (ECNH 2010; Bioethics Commission 2010). This technology leads to the fact that the distinction between life and nonlife is no longer clear. Synthetically created organisms have characteristics that define life, for example nucleic acid, metabolism and the capacity to multiply. For this reason critics of synthetic biology feel that the use of this technology will necessarily result in the uniqueness of life being lost - nothing about life is unique and unknowable any more (Bioethics Commission 2010). In answer, some theologians argue that, because human beings know how biochemical processes work, does not take away the mystery and value of human life. The mystery of existence can, from a Christian perspective, be found in the statement that there is indeed existence over and against no existence, and that there is not nothing, but something (Bioethics Commission 2010).

\section{Human beings historically visible}

Hefner (1989) notes that, throughout history, humanity has developed and created things that did not exist before. Albright (2001) writes in this regard:

Co-creators of many types have flourished, especially in the science of recent centuries, and this fact deserves to be celebrated as a gift from God to our species. (p. 259)

In an enlightening article, Albright (2001) shows how people established new entities in different areas in the past. They indeed acted as co-creators of God with the result that synthetic biology is definitely not the first instance where humans have created something new or acted as co-creators. In human history there are several examples where humans have established new entities through the rearrangement of existing matter of which some did not exist naturally. Albright (ibid) distinguishes between substances, subatomic and genetic creations in which humans act as co-creators. Amongst substances one can refer to urea, ${ }^{13}$ carborundum, artificial rubber, synthetic materials (nylon, orlon, rayon) and also different kinds of plastic. In addition, computers and other electronic equipment that depend on silicon

13.The synthesis of this organic compound by Friedrich Wöhler in 1828 from an inorganic precursor was an important milestone in the development of organic chemistry, as it showed for the first time that a molecule found in living organisms could be synthesised in the laboratory without biological starting materials (thus contradicting a theory, called vitalism, widely prevalent at one time. 
(from silicon dioxide), which can only be manufactured synthetically, can be mentioned. Subatomically, humans have created positrons (anti-matter) through experiments, calculated transmutation (where elements in the existing nucleus are changed into another nuclear species through bombardment; this way lead can be changed into gold), nuclear fission (synthetic plutonium, the nuclear bomb and power generation) and fusion (the hydrogen bomb). Lastly, one can refer to the genetic manipulation of plants and animals, cloning (something that does not occur in nature) and artificial selection of characteristics (for instance, the change from a wolf to a Pekinese, wild cabbage into cauliflower and maize (see Dawkins 2009) and, without a doubt, synthetic biology.

\section{Conclusion}

Hefner (1998:187) makes the following remark: 'The concept of humans as God's created co-creators is an attempt to make sense of science and technology.'

Theological concepts such as creatio continua and imago Dei do indeed help us understand and found modern technological development. God brought forth a new creation in the beginning and he continuously creates new things in his creation. Simultaneously God created human beings in his own image. This means that he decided what the relationship between human beings and nature should be. God created humans in such a way that they will keep developing new things and create new things as he does. In light of this theological argument, one can say that synthetic biology is not inherently unethical as long as it is executed responsibly.

\section{Acknowledgements Competing interests}

The author declares that he has no financial or personal relationship(s) that may have inappropriately influenced him in writing this article.

\section{References}

Albright, J.R., 2001, 'Scientific views of the created co-creator', Currents in Theology and Mission 28(3-4), 254-259.

Berkhof, H., 1985, Christelijk geloof: Een inleiding tot de geloofsleer, G.F. Callenbach, Nijkerk.

Cole-Turner, R., 2006, 'Biotechnology and the religion-Science discussion', in P. Clayton (ed.), The Oxford Handbook of Religion and Science, pp. 929-944, Oxford University Press, New York. http://dx.doi.org/10.1093/oxfordhb/9780199279272.003.0055
Crook, R.H., 2007, An introduction to Christian ethics, Prentice Hall, Pearson, New Jersey.

Dabrock, P., 2009, 'Playing God? Synthetic biology as theological and ethical challenge', Systems and Synthetic Biology 3, 47-54. http://dx.doi.org/10.1007/s11693-0099028-5

Dawkins, R., 2004, A pilgrimage to the dawn of life: The ancestor's tale, Orion Books, London.

Dawkins, R., 2009, The greatest show on earth: The evidence for evolution, Transworld Publishers, London.

De Nieuwe Katechismus, 1966, Geloofsverkondiging voor volwassenen in opdracht van de bisschoppen van Nederland, Paul Brand Hilversum, Antwerpen.

Douma, J., 1997, Medische Ethiek, Kok Uitgeverij, Kampen.

Federal Ethics Committee on Non-Human Biotechnology (ECNH), 2010, 'Synthetic Biology - Ethical Considerations: Report of the ECNH', viewed 05 November 2011, from www.ekah.admin.ch.s

Garfinkel, M.S., Endy, D., Epstein, G.L. \& Friedman, R.M., 2008, 'Synthetic biology', in M. Crowley (ed.), From birth to death and bench to clinic: The Hastings Center bioethics briefing book for journalists, policymakers, and campaigns, pp. 163-168, The Hastings Center, New York.

Hansen, B. \& Schotsman, P., 2005, 'Stem cell research: A theological interpretation', in L.S. Cahill (ed.), Genetics, theology and ethics. An interdisciplinary conversation, pp. 15-53, The Crossroad Publishing Company, New York.

Hefner, P., 1989, 'The evolution of the created co-creator', in T. Peters (ed.), Cosmos as creation: Theology and science in consonance, pp. 512-525, Abingdon, Nashville.

Hefner, P., 1993, The human factor: Evolution, culture, and religion, Fortress Press, Minneapolis.

Hefner, P., 1998, 'Biocultural evolution and created co-creator', in T. Peters (ed.), Science \& theology. The new Consonance, pp. 174-188, Westview Press, Oxford.

Hefner, P., 2005, 'Can the created co-creator be Lutheran? A response to Svend Anderson', Dialog: A Journal of Theology 44(22), 184-188. http://dx.doi. org/10.1111/j.0012-2033.2005.00255.x

Hefner, P., 2007, 'Genetic frontiers: Challenges for humanity and our religious traditions', Zygon: Journal of Religion and Science 42(1), 183-191. http://dx.doi.org/10.1111/ j.1467-9744.2006.00814.x

König, A., 2001, Fokus op die 300 geloofsvrae wat mense die meeste pla: 'n Verwysingsgids vir elke huis, Lux Verbi BM, Wellington.

König, A., 2010, Alle paaie lei na Jesus: Hoe die groot temas van die Bybel op Jesus uitloop, Christelike Uitgewersmaatskappy, Vereeniging.

Kuyper, A., 1910, 'Het dominium van den mensch', Dictaten dogmatiek, part 2, pp. 123126, Kok, Kampen. (Locus de Creaturis, C. Locum homine, §12).

Moltmann, J., 1985, God in creation: An ecological doctrine of creation, SCM Press, London.

Moltmann, J., 2012, Ethics of hope, SCM Press, London.

Pannenberg, W., 2006, 'Contributions from systematic theology: History and continuous creation', in P. Clayton (ed.), The Oxford handbook of religion and science,
pp. 359-371, Oxford University Press, New York. http://dx.doi.org/10.1093/ pp. 359-371, Oxford University P
oxfordhb/9780199279272.003.0023

Parens, E., Johnston, J. \& Moses, J., 2009, Ethical issues in synthetic biology: An overview of the debates, Woodrow Wilson International Center for Scholars, The Hastings Center, New York, Garrison.

Peters, T., 2005, 'Techno-secularism, religion, and the created co-creator', Zygon: Journal of Religion and Science 40(4), 845-862. http://dx.doi.org/10.1111/j.14679744.2005.00712.x

Polkinghorne, J., 2006, 'Christianity and science: Creation', in P. Clayton (ed.), The Oxford handbook of religion and science, pp. 57-70, Oxford University Press, New York. http://dx.doi.org/10.1093/oxfordhb/9780199279272.003.0005

Presidential Commission for the Study of Bioethical Issues (Bioethics Commission), 2010, 'New Directions: The ethics of synthetic biology and emerging technologies', viewed 03 January 2011, from www.bioethics.gov

Van Genderen, J. \& Velema, W.H., 1992, Beknopte Gereformeerde dogmatiek, Uitgeverij Kok, Kampen.

Vorster, J.M., 2004, Ethical perspectives on human rights, Potchefstroom Theological Publications, Potchefstroom

Vorster, N., 2011, Created in the image of God: Understanding God's relationship with humanity, Pickwick Publications, Oregon. 